\title{
PENGARUH BEBAN KERJA, PENILAIAN PRESTASI KERJA, DAN PENGEMBANGAN KARIER TERHADAP KINERJA KARYAWAN PT SURYA PROGARD, JAKARTA SELATAN
}

\author{
Farial Balqis ${ }^{1}$ \\ Edi Sugiono 2 \\ ${ }^{1,2}$ Fakultas Ekonomi dan Bisnis Universitas Nasional \\ Email: edisugiono33@yahoo.com ${ }^{2}$
}

\begin{abstract}
ABSTRAK
Penelitian ini bertujuan untuk menganalisis pengaruh beban kerja, penilaian prestasi kerja, dan pengembangan karier terhadap kinerja karyawan PT Surya Progard, Jakarta Selatan. Data penelitian yang digunakan adalah data primer dalam bentuk kuesioner dari 113 responden. Dengan menggunakan metode regresi linier berganda, hasil penelitian menunjukkan bahwa beban kerja, penilaian prestasi kerja, dan pengembangan karier secara parsial berpengaruh positif dan signifikan terhadap kinerja karyawan.
\end{abstract}

Kata kunci: Beban kerja, penilaian prestasi kerja, pengembangan karier, kinerja karyawan

\begin{abstract}
This study aims to analyze the impact of workload, performance appraisal, and career development on the employee performance of PT Surya Progard, South Jakarta. The research data used is primary data in the form of questionnaires from 113 respondents. By using multiple linear regression method, the results showed that workload, performance appraisal, and career development partially has positive and significant effect on employee performance.
\end{abstract}

Keywords: Workload, performance appraisal, career development, employee performance

\section{PENDAHULUAN}

Perusahaan yang siap berkompetisi harus memiliki manajemen yang efektif. Manajemen yang efektif yang dimaksudkan disini adalah manajemen yang dapat mempertahankan kinerja karyawannya pada level yang baik atau bahkan justru meningkatkan kinerja karyawannya tersebut. Hal ini sangat penting untuk dilakukan mengingat karyawan merupakan penggerak utama perusahaan yang secara langsung menentukan keberhasilan perusahaan.

Kinerja itu sendiri dapat dipengaruhi oleh beberapa faktor. Salah satunya adalah beban kerja. Menurut Pierce (2001), beban kerja yang tinggi merupakan salah satu penyebab ketidaksenangan karyawan terhadap pekerjaan yang dapat mengakibatkan kelelahan kerja. Beban kerja juga berdampak terhadap fisik dan psikis, sehingga dapat mengganggu kinerja karyawan. Selain beban kerja yang terlalu tinggi, beban kerja yang 
terlalu rendah juga dapat menurunkan kinerja karyawan karena akan membuat kemampuan yang ada di dalam diri karyawan menjadi tidak dapat dipergunakan dengan optimal. Beban kerja yang terlalu rendah juga dapat menimbulkan kebosanan, kehilangan kepedulian situasi, dan mengurangi kepekaan terhadap lingkungan sekitar. Dalam hal ini, Muhammad dkk. (2016) bahkan telah membuktikan bahwa beban kerja berpengaruh positif dan signifikan terhadap kinerja karyawan. Dengan kata lain, beban kerja yang tidak sesuai dengan kemampuan karyawan dapat berakibat pada ketidakoptimalan kinerja karyawan.

Faktor lain yang dapat mempengaruhi kinerja karyawan adalah penilaian prestasi kerja. Wiese dan Buckley (1998) menyatakan bahwa proses penilaian kinerja memungkinkan organisasi untuk mengukur dan mengevaluasi perilaku karyawan individu dan prestasi selama periode waktu tertentu. Penilaian prestasi ini mencerminkan bahwa para karyawan memperoleh perhatian dari atasannya, sehingga dapat mendorong mereka untuk bergairah dalam bekerja dan pada akhirnya meningkatkan kinerjanya. Hal ini sejalan dengan hasil penelitian yang dilakukan oleh Rismansyah (2012) yang menunjukkan bahwa penilaian prestasi kerja berpengaruh positif dan signifikan terhadap kinerja karyawan.

Kinerja karyawan juga dapat dipengaruhi oleh pengembangan karier. Menurut Nawawi (2001), pengembangan karier itu sendiri bukanlah sekedar promosi jabatan ke posisi yang lebih tinggi, melainkan juga merupakan dorongan bagi karyawan untuk lebih maju dalam bekerja, yakni dengan meningkatkan pengetahuan dan keterampilan/keahlian, sehingga dapat menjadi lebih berprestasi sebagai pekerja yang kompetitif. Pengembangan karier pada akhirnya memang ditujukan untuk menciptakan kinerja karyawan yang lebih baik dengan cara meningkatkan kemampuan mereka. Hal ini didukung oleh hasil penelitian yang dilakukan oleh Distyawaty (2017) yang menunjukkan bahwa pengembangan karier berpengaruh positif dan signifikan terhadap kinerja karyawan.

Setiap perusahaan dituntut untuk dapat senantiasa meningkatkan kinerjanya. Hal ini juga berlaku pada PT Surya Progard yang bergerak di bidang aksesoris mobil serta penyediaan layanan aplikasi anti karat, peredam suara, dan pelindung cat pada kendaraan yang memberikan perlindungan kepada kendaraan. Berikut ini disajikan tabel data capaian kinerja PT Surya Progard pada periode 2015-2017. 
Tabel 1. Data Capaian Kinerja PT Surya Progard

Periode 2015-2017

\begin{tabular}{|c|c|c|c|c|}
\hline \multirow{2}{*}{ Aspek Penilaian } & \multicolumn{3}{|c|}{ Tahun } & \multirow{2}{*}{$\begin{array}{c}\text { Target } \\
\text { Pencapaian }\end{array}$} \\
\hline & 2015 & 2016 & 2017 & \\
\hline $\begin{array}{l}\text { Melakukan pekerjaan dengan baik sesuai } \\
\text { kualitas kerja yang ditentukan perusahaan }\end{array}$ & $80 \%$ & $78 \%$ & $87 \%$ & $100 \%$ \\
\hline $\begin{array}{l}\text { Kemampuan bekerja sama dengan baik di } \\
\text { dalam perusahaan }\end{array}$ & $78 \%$ & $69 \%$ & $89 \%$ & $100 \%$ \\
\hline $\begin{array}{l}\text { Berupaya untuk mencapai standar kinerja } \\
\text { tertinggi untuk meningkatkan mutu bisnis }\end{array}$ & $83 \%$ & $76 \%$ & $89 \%$ & $100 \%$ \\
\hline $\begin{array}{l}\text { Memiliki komitmen yang baik dalam } \\
\text { lingkungan kerja }\end{array}$ & $80 \%$ & $79 \%$ & $83 \%$ & $100 \%$ \\
\hline $\begin{array}{l}\text { Memiliki kemampuan dalam menyelesaikan } \\
\text { pekerjaan yang ditentukan perusahaan }\end{array}$ & $78 \%$ & $75 \%$ & $80 \%$ & $100 \%$ \\
\hline
\end{tabular}

(Sumber: Data HRD, 2019)

Berdasarkan data di atas, capaian kinerja karyawan PT Surya Progard terlihat berfluktuasi selama periode 2015-2017. Meskipun ada kecenderungan yang positif, kinerja karyawan masih belum optimal karena belum mencapai target yang telah ditetapkan. Oleh karena itu, perlu dilakukan penelitian untuk menganalisis pengaruh berbagai faktor yang relevan terhadap kinerja karyawan PT Surya Progard untuk dapat dijadikan sebagai alat dalam mengoptimalisasi kinerja karyawan di kemudian hari. Dalam hal ini, faktor-faktor yang dianalisis mencakup beban kerja, penilaian prestasi kerja, dan pengembangan karier sebagaimana yang telah diuraikan sebelumnya.

\section{TINJAUAN PUSTAKA}

\section{Kinerja}

Kinerja adalah suatu keluaran yang dihasilkan berbagai fungsi atau indikator dari suatu pekerjaan atau profesi dalam kurun waktu tertentu (Wirawan, 2009:5). Adapun Mangkunegara (2011) mengartikan kinerja sebagai kualitas dan kuantitas dari hasil pekerjaan yang dijalankan oleh karyawan sesuai dengan standar kerja yang telah ditetapkan (Mangkunegara, 2011).

Menurut Sutrisno (2016), terdapat beberapa faktor yang dapat mempengaruhi kinerja karyawan, yaitu sebagai berikut.

1. Efektivitas dan efisiensi, yakni faktor yang menjadi ukuran baik buruknya kinerja organisasi. 
2. Otoritas dan tanggung jawab, dimana dalam organisasi yang baik, wewenang dan tangung jawab telah didelegasikan dengan baik dengan tanpa adanya tumpangtindih tugas.

3. Disiplin, yakni suatu kondisi atau sikap hormat yang ada pada diri karyawan terhadap peraturan dan ketetapan perusahaan.

4. Inisiatif, yakni segala sesuatu yang berkaitan dengan daya pikir dan kreativitas dalam bentuk ide untuk merencanakan sesuatu yang berkaitan dengan tujuan organisasi.

\section{Beban Kerja}

Hancock dan Meshkati (1988) mendefinisikan beban kerja sebagai perbedaan antara kemampuan pekerjaan dan tuntutan pekerjaan. Menurut Hart dan Staveland (1988), beban kerja adalah sesuatu yang muncul dari interaksi antara tuntutan tugas-tugas, lingkungan kerja yang digunakan sebagai tempat kerja, keterampilan, perilaku, dan persepsi dari pekerja. Beban kerja terkadang juga dapat didefinisikan secara operasional pada berbagai faktor, seperti tuntutan tugas atau upaya-upaya yang dilakukan untuk melakukan pekerjaan.

Hart dan Staveland (1988) menjelaskan bahwa terdapat tiga faktor utama yang menentukan beban kerja, yaitu tuntutan tugas (task demands), usaha atau tenaga (efforts), dan performansi. Adapun Koesomowidjojo (2017:22) membagi beban kerja ke dalam dua jenis, yaitu sebagai berikut.

1. Beban kerja kuantitatif, yakni beban kerja yang menunjukkan jumlah atau besarnya pekerjaan yang harus dilaksanakan, seperti tingginya jam kerja, besarnya tekanan kerja, atau besarnya tanggung jawab atas pekerjaan yang diampunya.

2. Beban kerja kualitatif, yakni beban kerja yang berhubungan dengan kemampuan pekerja dalam melaksanakan pekerjaan yang diampunya.

\section{Penilaian Prestasi Kerja}

Penilaian prestasi kerja (performance appraisal) adalah suatu proses dimana organisasi mengevaluasi atau menilai prestasi kerja karyawannya (Sunyoto, 2016). Menurut Sutrisno (2016), penilaian prestasi kerja pada dasarnya ditujukan untuk memperoleh informasi yang berguna dalam pengambilan keputusan yang berkaitan dengan manajemen sumber daya manusia yang lain, seperti perencanaan dan pengembangan 
karier, program-program kompensasi, promosi, demosi, pensiun, dan pemberhentian atau pemecatan karyawan.

Secara lebih rinci lagi, Samsudin (2012) menjelaskan bahwa tujuan penilaian prestasi kerja antara lain sebagai berikut.

1. Administratif, yaitu memberikan arah untuk penetapan promosi, transfer, dan kenaikan gaji.

2. Informatif, yaitu memberikan data kepada manajemen tentang prestasi kerja bawahannya dan memberikan data kepada individu tentang kelebihan dan kekurangannya.

3. Motivasi, yaitu menciptakan pengalaman belajar yang memotivasi staf untuk mengembangkan diri dan meningkatkan prestasi kerja mereka.

\section{Pengembangan Karier}

Pengembangan karier merupakan suatu upaya atau langkah yang dilakukan oleh karyawan dan/atau pimpinan sumber daya manusia dalam rangka mengembangkan potensi karyawan untuk dapat menduduki jabatan yang lebih tinggi dalam suatu usaha mencapai tujuan perusahaan (Bahri, 2016). Menurut Hady (2013), pengembangan karier dapat diartikan sebagai suatu kondisi yang menunjukkan adanya peningkatan-peningkatan status seseorang dalam organisasi dalam jalur karier yang telah ditetapkan dalam organisasi tersebut.

Pengembangan karier bertujuan untuk mengembangkan para pegawai agar dapat dipromosikan, mengungkapkan potensi pegawai, mendorong pertumbuhan, mengurangi penimbunan, memuaskan kebutuhan pegawai, dan meningkatkan karier pegawai (Handoko, 2000). Menurut Rivai (2004), faktor- faktor yang mempengaruhi pengembangan karier antara lain meliputi prestasi kerja (job performance), eksposur, jaringan kerja, kesetiaan terhadap organisasi, serta pembimbing dan sponsor.

\section{Keterkaitan Antar Variabel Penelitian}

\section{Keterkaitan antara Beban Kerja dan Kinerja Karyawan}

Beban kerja yang terlalu rendah dapat menurunkan kinerja karyawan karena akan membuat kemampuan yang ada di dalam diri karyawan menjadi tidak dapat dipergunakan dengan optimal. Beban kerja yang terlalu rendah juga dapat menyebabkan karyawan mengalami kebosanan, kehilangan kepedulian situasi, dan mengurangi kepekaannya 
terhadap lingkungan sekitar. Dengan kata lain, beban kerja yang tidak sesuai dengan kemampuan karyawan dapat berakibat pada ketidakoptimalan kinerja karyawan. Hal ini didukung oleh hasil penelitian yang dilakukan Muhammad dkk. (2016) yang menunjukkan bahwa beban kerja berpengaruh positif dan signifikan terhadap kinerja karyawan. Artinya, peningkatan beban kerja hingga batas yang normal sesuai dengan kemampuan karyawan terbukti dapat meningkatkan kinerja karyawan.

$\mathrm{H}_{1}$ : Beban kerja berpengaruh positif dan signifikan terhadap kinerja karyawan PT Surya Progrard.

\section{Keterkaitan antara Penilaian Prestasi Kerja dan Kinerja Karyawan}

Wiese dan Buckley (1998) menyatakan bahwa proses penilaian kinerja memungkinkan organisasi untuk mengukur dan mengevaluasi perilaku karyawan individu dan prestasi selama periode waktu tertentu. Penilaian prestasi ini mencerminkan bahwa para karyawan memperoleh perhatian dari atasannya, sehingga dapat mendorong mereka untuk bergairah dalam bekerja dan pada akhirnya meningkatkan kinerjanya. Hal ini didukung oleh hasil penelitian yang dilakukan Rismansyah (2012) yang menunjukkan bahwa penilaian prestasi kerja berpengaruh positif dan signifikan terhadap kinerja karyawan.

$\mathrm{H}_{2}$ : Penilaian prestasi kerja berpengaruh positif dan signifikan terhadap kinerja karyawan PT Surya Progrard.

\section{Keterkaitan antara Pengembangan Karier dan Kinerja Karyawan}

Menurut Nawawi (2001), pengembangan karier bukanlah sekedar promosi jabatan ke posisi yang lebih tinggi, melainkan juga merupakan dorongan bagi karyawan untuk lebih maju dalam bekerja, yakni dengan meningkatkan pengetahuan dan keterampilan/keahlian, sehingga dapat menjadi lebih berprestasi sebagai pekerja yang kompetitif. Pengembangan karier itu sendiri pada akhirnya memang ditujukan untuk menciptakan kinerja karyawan yang lebih baik dengan cara meningkatkan kemampuan mereka. Hal ini didukung oleh hasil penelitian yang dilakukan oleh Distyawaty (2017) yang menunjukkan bahwa pengembangan karier berpengaruh positif dan signifikan terhadap kinerja karyawan.

$\mathrm{H}_{3}$ : Pengembangan karier berpengaruh positif dan signifikan terhadap kinerja karyawan PT Surya Progrard. 


\section{Kerangka Pemikiran}

Kerangka pemikiran yang digunakan dalam penelitian ini dapat dilihat sebagai berikut.

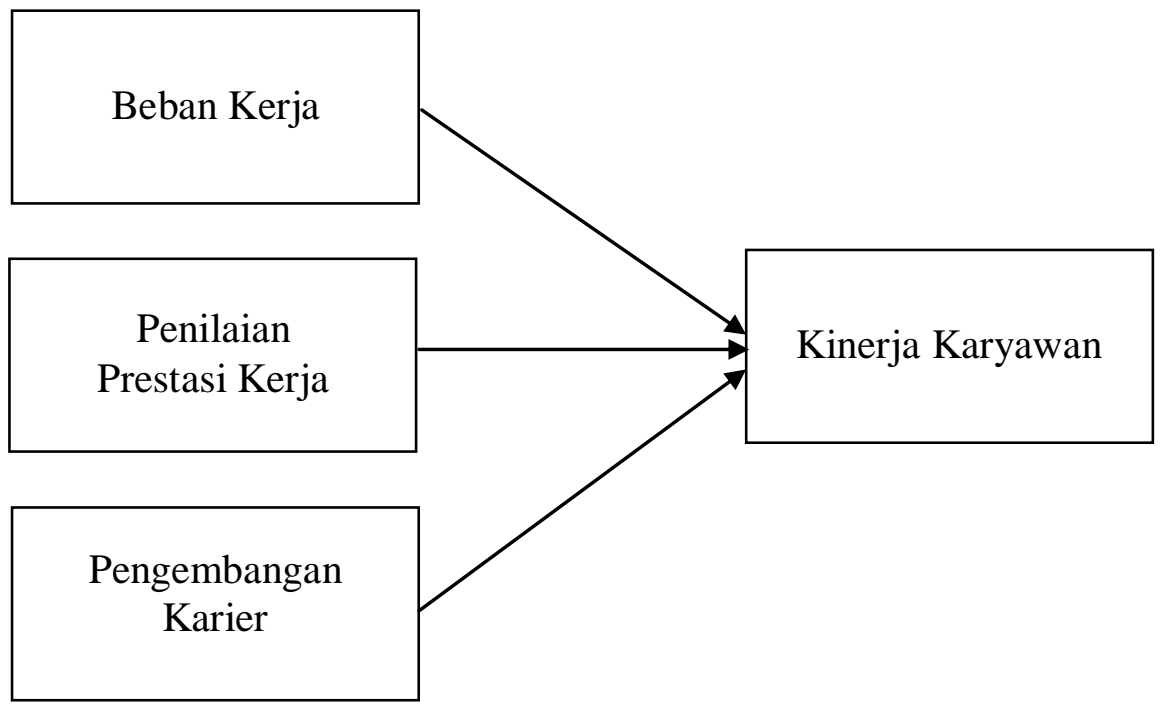

Gambar 1. Kerangka Pemikiran

\section{METODOLOGI PENELITIAN}

\section{Sumber dan Jenis Data}

Penelitian ini menggunakan data primer berjenis cross section yang diperoleh dari penyebaran kuesioner kepada responden untuk kemudian ditransformasikan ke dalam bentuk data kuantitatif dengan menggunakan skala Likert.

\section{Populasi dan Sampel}

Populasi penelitian ini adalah seluruh karyawan PT Surya Progard yang berjumlah 157 karyawan. Dengan menggunakan metode probabilty sampling berjenis simple random sampling, diperoleh sampel sebanyak 113 responden. Penentuan ukuran sampel tersebut dilakukan dengan menggunakan rumus Slovin.

\section{Metode Analisis}

Data dalam penelitian ini dianalisis dengan menggunakan metode regresi linear berganda dengan alat bantu berupa software SPSS. Model regresi digunakan untuk menganalisis pengaruh beban kerja, penilaian prestasi kerja, dan pengembangan karier terhadap kinerja karyawan PT Surya Progard dengan rumusan formula sebagai berikut. 


$$
\mathrm{Y}=\alpha+\mathrm{b}_{1} \mathrm{X}_{1}+\mathrm{b}_{2} \mathrm{X}_{2}+\mathrm{b}_{3} \mathrm{X}_{3}+\mathrm{e}
$$

Keterangan:

$\begin{array}{ll}\mathrm{Y} & =\text { Kinerja karyawan } \\ \alpha & =\text { Konstanta } \\ \mathrm{b}_{1}, \mathrm{~b}_{2}, \mathrm{~b}_{3} & =\text { Koefisien regresi } \\ \mathrm{X}_{1} & =\text { Beban kerja } \\ \mathrm{X}_{2} & =\text { Penilaian prestasi kerja } \\ \mathrm{X}_{3} & =\text { Pengembangan karier } \\ \mathrm{e} & =\text { Tingkat kesalahan }\end{array}$

\section{HASIL DAN PEMBAHASAN}

\section{Hasil Penelitian}

\section{Hasil Uji Instrumen}

Berdasarkan hasil uji validitas dan reliabilitas yang telah dilakukan, semua item pernyataan dinyatakan valid dan reliabel karena memiliki $\mathrm{r}_{\text {hitung }}$ yang lebih besar daripada $\mathrm{r}_{\text {tabel }}$ serta memiliki cronbach's alpha yang lebih besar daripada 0,6.

\section{Hasil Uji Asumsi Klasik}

Hasil uji normalitas dengan menggunakan Kolmogorov - Smirnov Test menunjukkan bahwa data terdistribusi normal karena memiliki asymp. sig. (2-tailed) sebesar 0,200 yang berarti lebih besar daripada 0,05. Adapun hasil uji multikolinearitas menunjukkan bahwa nilai VIF untuk variabel beban kerja, penilaian prestasi kerja, dan pengembangan karier secara berturut-turut adalah 1,411, 1,366, dan 1,254. Adapun besar nilai tolerance-nya secara berturut-turut adalah $0,709,0,732$, dan 0,797 . Oleh karena memiliki nilai VIF yang lebih daripada 10 dan nilai tolerance yang lebih besar daripada 0,1, maka model regresi dinyatakan terbebas dari multikolineraitas.

Hasil uji glejser menunjukkan bahwa variabel beban kerja, penilaian prestasi kerja, dan pengembangan karier memiliki nilai signifikansi secara berturut-turut seesar 0,199, 0,269, dan 0,911 yang semuanya lebih besar daripada 0,05. Dengan demikian, dapat disimpulkan bahwa tidak terjadi masalah heteroskedastisitas pada model yang digunakan. Adapun hasil uji autokorelasi menunjukkan bahwa nilai Durbin-Watson berada di antara 
dU dan (4-dU), yakni 1,7480 < 1,244 <2,252, sehingga tidak terjadi autokorelasi dalam model regresi yang digunakan.

\section{Hasil Uji Regresi Linear Berganda}

Berdasarkan hasil uji regresi linear berganda yang telah dilakukan, diperoleh persamaan sebagai berikut.

$$
Y=0,273+0,253 X_{1}+0,538 X_{2}+0,208 X_{3}
$$

Keterangan:

$\mathrm{Y}=$ Kinerja karyawan

$\mathrm{X}_{1}=$ Beban kerja

$\mathrm{X}_{2}=$ Penilaian prestasi kerja

$\mathrm{X}_{3}=$ Pengembangan karier

Arti dari persamaan di atas dapat dijelaskan sebagai berikut.

a. Konstanta sebesar 0,273 menunjukkan bahwa apabila variabel beban kerja, penilaian prestasi kerja, dan pengembangan karier bernilai nol, maka kinerja karyawan akan bernilai 0,273.

b. Koefisien regresi untuk variabel beban kerja menunjukkan nilai positif sebesar 0,253, sehingga jika beban kerja mengalami kenaikan sebesar satu satuan, maka kinerja karyawan akan mengalami peningkatan sebesar 0,253 atau 25,3\% dengan asumsi variabel bebas lainnya bernilai tetap.

c. Koefisien regresi untuk variabel penilaian prestasi kerja menunjukkan nilai positif sebesar 0,538, sehingga jika penilaian prestasi kerja mengalami kenaikan sebesar satu satuan, maka kinerja karyawan akan mengalami peningkatan sebesar 0,538 atau $53,8 \%$ dengan asumsi variabel bebas lainnya bernilai tetap.

d. Koefisien regresi untuk variabel pengembangan karier menunjukkan nilai positif sebesar 0,208, sehingga jika pengembangan karier mengalami kenaikan sebesar satu satuan, maka kinerja karyawan akan mengalami peningkatan sebesar 0,208 atau $20,8 \%$ dengan asumsi variabel bebas lainnya bernilai tetap.

\section{Hasil Uji Kelayakan Model}

Uji F menghasilkan nilai signifikansi sebesar 0,000 yang lebih kecil daripada 0,05. Hal tersebut menunjukkan beban kerja, penilaian prestasi kerja, dan pengembangan karier 
kerja secara bersama-sama berpengaruh signifikan terhadap kinerja karyawan PT Surya Progard, sehingga model yang digunakan dalam penelitian dinyatakan valid. Dengan koefisien determinasi $\left(\mathrm{R}^{2}\right)$ sebesar 0,544, tingkat variabel kinerja karyawan dapat dipengaruhi oleh beban kerja, penilaian prestasi kerja, dan pengembangan karier adalah sebesar $54,4 \%$, sedangkan $45,6 \%$ sisanya dipengaruhi oleh faktor-faktor lain yang tidak dianalisis dalam penelitian ini.

\section{Hasil Uji Hipotesis}

Tabel 2. Hasil Uji t

\begin{tabular}{|l|c|c|}
\hline \multicolumn{1}{|c|}{ Variabel } & t & Sig. \\
\hline Beban kerja & 2,697 & 0,008 \\
\hline Penilaian prestasi kerja & 6,698 & 0,000 \\
\hline Pengembangan karier & 2,683 & 0,008 \\
\hline
\end{tabular}

(Sumber: Data diolah, 2019)

Berdasarkan hasil uji t di atas, dapat dijelaskan hal-hal sebagai berikut.

1. Besarnya nilai $t_{\text {hitung }}$ untuk variabel beban kerja adalah 2,697 dengan tingkat signifikan sebesar 0,008, sedangkan besarnya nilai $\mathrm{t}_{\text {tabel }}$ dengan $\mathrm{df}=109(\mathrm{n}-\mathrm{k}-1=113-3-1)$ adalah 1,981. Oleh karena $t_{\text {hitung }}>t_{\text {tabel }}(2,697>1,981)$ dan nilai signifikan $<0,05$ $(0,008<0,05)$, maka $\mathrm{H}_{\mathrm{o}}$ ditolak dan $\mathrm{H}_{\mathrm{a}}$ diterima, sehingga beban kerja terbukti berpengaruh positif dan signifikan terhadap kinerja karyawan PT Surya Progard.

2. Besarnya nilai $t_{\text {hitung }}$ untuk variabel penilaian prestasi kerja adalah 6,698 dengan tingkat signifikan sebesar 0,000, sedangkan besarnya nilai $\mathrm{t}_{\text {tabel }}$ dengan $\mathrm{df}=109(\mathrm{n}-\mathrm{k}$ $-1=113-3-1)$ adalah 1,981 . Oleh karena $t_{\text {hitung }}>t_{\text {tabel }}(6,698>1,981)$ dan nilai signifikan $<0,05(0,000<0,05)$, maka $\mathrm{H}_{\mathrm{o}}$ ditolak dan $\mathrm{H}_{\mathrm{a}}$ diterima, sehingga penilaian prestasi kerja terbukti berpengaruh positif dan signifikan terhadap kinerja karyawan PT Surya Progard.

3. Besarnya nilai $t_{\text {hitung }}$ untuk variabel pengembangan karier adalah 2,683 dengan tingkat signifikan sebesar 0,008, sedangkan besarnya nilai $t_{\text {tabel }}$ dengan $\mathrm{df}=109(\mathrm{n}-\mathrm{k}-1=$ $113-3-1)$ adalah 1,981 . Oleh karena $t_{\text {hitung }}>t_{\text {tabel }}(2,683>1,981)$ dan nilai signifikan $<0,05(0,008<0,05)$, maka $\mathrm{H}_{\mathrm{o}}$ ditolak dan $\mathrm{H}_{\mathrm{a}}$ diterima, sehingga pengembangan karier terbukti berpengaruh positif dan signifikan terhadap kinerja karyawan PT Surya Progard. 


\section{Pembahasan}

\section{Pengaruh Beban Kerja terhadap Kinerja Karyawan}

Hasil penelitian ini membuktikan bahwa beban kerja berpengaruh positif dan signifikan terhadap kinerja karyawan PT Surya Progard. Hal tersebut menunjukkan bahwa peningkatan beban kerja hingga batas yang normal sesuai dengan kemampuan karyawan terbukti dapat meningkatkan kinerja karyawan. Dengan kata lain, pada saat atau kondisi tertentu, beban kerja justru dapat menjadi stimulus bagi karyawan untuk menghasilkan prestasi kerja yang baik. Akan tetapi, besarnya beban kerja tersebut harus berada dalam batas wajar dan sesuai dengan kemampuan karyawan karena beban kerja yang berlebih pada akhirnya dapat menimbulkan stres kerja ataupun gangguan kesehatan pada karyawan yang bersangkutan.

Beban kerja yang terlalu rendah dapat menurunkan kinerja karyawan karena akan membuat kemampuan yang ada di dalam diri karyawan menjadi tidak dapat dipergunakan dengan optimal. Beban kerja yang terlalu rendah juga dapat menyebabkan karyawan mengalami kebosanan, kehilangan kepedulian situasi, dan mengurangi kepekaannya terhadap lingkungan sekitar. Dengan kata lain, beban kerja yang tidak sesuai dengan kemampuan karyawan dapat berakibat pada ketidakoptimalan kinerja karyawan. Hal ini didukung oleh hasil penelitian yang dilakukan Muhammad dkk. (2016) serta Adityawarman dkk. (2015) yang menunjukkan bahwa beban kerja berpengaruh positif dan signifikan terhadap kinerja karyawan.

\section{Pengaruh Penilaian Prestasi Kerja terhadap Kinerja Karyawan}

Hasil penelitian ini membuktikan bahwa penilaian prestasi kerja berpengaruh positif dan signifikan terhadap kinerja karyawan PT Surya Progard. Hal tersebut menunjukkan bahwa semakin baik penilaian prestasi kerja yang diterapkan dalam perusahaan, maka semakin baik pula kinerja karyawan yang bersangkutan. Hal ini sejalan dengan hasil penelitian yang dilakukan Rismansyah (2012) dan Kamal (2018) yang menunjukkan bahwa penilaian prestasi kerja berpengaruh positif dan signifikan terhadap kinerja karyawan.

Wiese dan Buckley (1998) menyatakan bahwa proses penilaian kinerja memungkinkan organisasi untuk mengukur dan mengevaluasi perilaku karyawan individu dan prestasi selama periode waktu tertentu. Penilaian prestasi ini mencerminkan bahwa para karyawan memperoleh perhatian dari atasannya, sehingga dapat mendorong mereka 
untuk bergairah dalam bekerja dan pada akhirnya meningkatkan kinerjanya. Samsudin (2012) menjelaskan bahwa penilaian prestasi kerja itu sendiri memang ditujukan untuk memberikan data kepada manajemen tentang prestasi kerja karyawan dan memberikan data kepada karyawan yang bersangkutan tentang kelebihan dan kekurangannya, sehingga dapat memotivasi karyawan tersebut untuk mengembangkan dirinya dan meningkatkan prestasi kerjanya yang pada akhirnya akan meningkatkan kinerjanya.

\section{Pengaruh Pengembangan Karier terhadap Kinerja Karyawan}

Hasil penelitian ini membuktikan bahwa pengembangan karier berpengaruh positif dan signifikan terhadap kinerja karyawan PT Surya Progard. Hal tersebut menunjukkan bahwa semakin baik pengembangan karier yang diterapkan dalam perusahaan, maka semakin baik pula kinerja karyawan yang bersangkutan. Hal ini sejalan dengan hasil penelitian yang dilakukan oleh Distyawaty (2017) dan Manansal dkk. (2018) yang menunjukkan bahwa pengembangan karier berpengaruh positif dan signifikan terhadap kinerja karyawan. Pemberlakuan pengembangan karier dengan cara pendidikan dan pelatihan serta promosi dan rotasi penugasan mampu meningkatkan kinerja karyawan yang ditandai dengan prestasi kerja yang baik, disiplin kerja yang meningkat, ketepatan waktu, kehadiran yang optimal, dan hubungan antar karyawan yang baik.

Didasarkan pada kenyataan bahwa seorang karyawan/pegawai akan membutuhkan serangkaian pengetahuan, keahlian dan kemampuan yang berkembang untuk bekerja dengan baik dan suksesi posisi yang ditemui selama kariernya, maka pengembangan karier merupakan hal yang penting dilakukan untuk merubah sumber daya manusia yang dimiliki organisasi, dari suatu keadaan ke keadaan lain yang lebih baik melalui pendidikan jangka panjang dan pengalaman belajar dalam mempersiapkan pegawai atas suatu tanggung jawab tertentu di masa mendatang. Pengembangan karier itu sendiri pada akhirnya memang ditujukan untuk menciptakan kinerja karyawan yang lebih baik dengan cara meningkatkan kemampuan mereka. Apabila karyawan/pegawai semula sudah berkinerja positif, maka pengembangan karier akan ditujukan untuk semakin meningkatkan prestasi karyawan tersebut dalam proses menapaki jenjang karier. Adapun apabila karyawan/pegawai semula berkinerja negatif, maka pengembangan karier akan ditujukan untuk memperbaikinya kinerja tersebut ke arah yang positif. 


\section{KESIMPULAN DAN SARAN}

\section{Kesimpulan}

Berdasarkan hasil dan pembahasan penelitian ini, dapat ditarik kesimpulan sebagai berikut.

1. Beban kerja berpengaruh positif dan signifikan terhadap kinerja karyawan PT Surya Progard.

2. Penilaian prestasi kerja berpengaruh positif dan signifikan terhadap kinerja karyawan PT Surya Progard.

3. Pengembangan karier berpengaruh positif dan signifikan terhadap kinerja karyawan PT Surya Progard.

\section{Saran}

Adapun saran-saran yang dapat diberikan sehubungan dengan hasil penelitian ini antara lain sebagai berikut.

1. Pada bagian dengan beban kerja bertensi rendah, sebaiknya sebagian karyawannya dipindahkan ke bagian dengan tensi kerja yang lebih tinggi untuk mengurangi beban kerja yang padat. Selain itu, manajemen juga harus senantiasa tepat dalam mendistribusikan beban kerja terhadap karyawannya sesuai dengan kemampuan karyawan yang bersangkutan dalam ambang batas normal.

2. Manajemen diharapkan dapat senantiasa menerapkan sistem penilaian kinerja yang efektif sebagai alat untuk mengevaluasi keunggulan dan kelemahan karyawannya dalam rangka meningkatkan prestasi kerja karyawan di masa mendatang.

3. Manajemen diharapkan dapat senantiasa menerapkan sistem pengembangan karier yang baik. Selain itu, manajemen diharapkan juga memberikan perhatian yang lebih besar lagi kepada karyawannya dalam bentuk pemberian fasilitas kesempatan belajar untuk pengembangan karier yang lebih baik lagi di masa mendatang.

\section{DAFTAR PUSTAKA}

Adityawarman, Y., B. Sanim, dan B.M. Sinaga. 2015. Pengaruh Beban Kerja terhadap Kinerja Karyawan PT Bank Rakyat Indonesia (Persero) Tbk Cabang Krekot. Jurnal Manajemen dan Organisasi. 6(1): 34-44.

Bahri, D. 2016. Pengaruh Pengembangan Karier dan Kompetensi terhadap Produktivitas Kerja serta Implikasinya pada Kinerja Pegawai Dinas PU Bina Marga Wilayah Kerja Sumatera Selatan. Journal Ecoment Global. 1(1): 51-61. 
Distyawaty. 2017. Pengaruh Kompetensi dan Pengembangan Karier terhadap Kinerja Karyawan Aparatur Pengawas Inspektorat Daerah Provinsi Sulawesi Tengah. Jurnal Katalogis. 5(4): 56-68.

Hady. 2013. Manajemen Sumber Daya Manusia. Pustaka Pelajar. Yogyakarta.

Hady, D. H. 2013. Hubungan Kompetensi, Pengembangan Karir, Kepuasan Kerja dengan Kinerja Pegawai pada Dinas Pendidikan Kabupaten Kotabumi Lampung Utara.

Hancock, P.A. dan N. Meshkati. 1988. Human Mental Workload. Elsevier Science Publisher B.V. Amsterdam.

Handoko, T.H. 2000. Manajemen Personalia dan Sumber Daya Manusia. Edisi 2. BPFE. Yogyakarta.

Hart, S.G. dan L.E. Staveland. 1988. Development of NASA-TLX (Task Load Index): Results of Empirical and Theoretical Research. Advances in Psychology. 52: 139183.

Kamal, F. 2018. Pengaruh Penilaian Prestasi Kerja terhadap Kinerja Karyawan PT Doceney Jakarta. Jurnal Penelitian Ekonomi dan Bisnis. 2(1): 11-20.

Koesomowidjojo, S.R.M. 2017. Panduan Praktis Menyusun Analisis Beban Kerja. Raih Asa Sukses. Jakarta.

Manansal. R., J.L. Sepang, dan D.N. Baramuli. 2016. Pengaruh Displin Kerja dan Pengembangan Karir terhadap Kinerja Karyawan pada Fakultas Ekonomi dan Bisnis UNSRAT di Manado. Jurnal Berkala Ilmiah Efisiensi. 16(1): 760-770.

Mangkunegara, A.A.A.P. 2011. Manajemen Sumber Daya Manusia Perusahaan. PT Remaja Rosda Karya. Bandung.

Muhammad, S.R., Adolfina, dan G. Lumintang. 2016. Pengaruh Lingkungan Kerja, Kompensasi dan Beban Kerja terhadap Kinerja Karyawan pada Dinas Pendapatan Daerah Kota Manado. Jurnal EMBA. 4(1): 45-55.

Nawawi, H. 2001. Manajemen Sumber Daya Manusia untuk Bisnis yang Kompetitif. Gadjah Mada University Press. Yogyakarta.

Pierce, J.R. 2001. Critical Thinking. McGraw Hill. New York.

Rismansyah. 2012. Pengaruh Penilaian Prestasi Kerja terhadap Kinerja Karyawan CV Empat Serangkai Palembang. Jurnal Wahana Media Ekonomi. 9(3): 36-50.

Rivai, V. 2004. Manajemen Sumber Daya Manusia untuk Perusahaan. Rajagrafindo Persada. Jakarta.

Samsudin, S. 2012. Manajemen Sumber Daya Manusia. CV Pustaka Setia. Jakarta. 
Sutrisno, E. 2016. Manajemen Sumber Daya Manusia. Kencana Prenadamedia Group. Jakarta.

Wiese, D.S. dan M.R. Buckley. 1998. The Evolution of the Performance Appraisal Process. Journal of Management History. 4(3): 233-249.

Wirawan. 2009. Evaluasi Kinerja Sumber Daya Manusia: Teori, Aplikasi, dan Penelitian. Salemba Empat. Jakarta. 